\title{
Surface plasmon resonance-induced visible-light photocatalytic performance of silver/silver molybdate composites
}

\author{
Xianglong Yang, Ying Wang, Xiao Xu, Yang Qu, Xing Ding\#, Hao Chen* \\ College of Science, Huazhong Agricultural University, Wuhan 430070, Hubei, China
}

\section{A R T I C L E I N F}

\section{Article history:}

Received 23 August 2016

Accepted 10 September 2016

Published 5 February 2017

\section{Keywords:}

Silver

Silver molybdate

Sodium dodecyl sulfate

Photocatalytic activity

Surface plasmon resonance

Rhodamine B

\begin{abstract}
A B S T R A C T
Novel silver/silver molybdate $\left(\mathrm{Ag} / \mathrm{Ag}_{2} \mathrm{MoO}_{4}\right)$ composites with surface plasmon resonance (SPR)-enhanced photocatalytic performance were successfully fabricated via a facile one-pot hydrothermal route with the presence of sodium dodecyl sulfate (SDS) in this study. The as prepared silver/silver molybdate $\left(\mathrm{Ag} / \mathrm{Ag}_{2} \mathrm{MoO}_{4}\right)$ composites were systematically characterized by X-ray diffraction (XRD), scanning electron microscopy (SEM) and ultraviolet-visible diffuse reflectance absorption spectroscopy (DRS) in order to investigate their crystal structure, morphology and optical property as well. The photocatalytic activities of the composites were subsequently evaluated by their ability to degrade rhodamine $\mathrm{B}(\mathrm{RhB})$ under visible-light irradiation. Varies of controlled experiments were then carefully operated to gain a deep insight into the assembling of $\mathrm{Ag} / \mathrm{Ag}_{2} \mathrm{MoO}_{4}$ composites. It was found that preparation conditions such as $\mathrm{pH}$, reaction time, and the amount of surfactant played important roles in the formation of composites with octahedral microstructures. And the composite obtained at $160^{\circ} \mathrm{C}$ using $0.5 \mathrm{~g}$ of sodium dodecyl sulfate exhibited the highest photocatalytic performance under visible-light irradiation. Capture experiments were also conducted to clarify the function of different active species generated on the surface of $\mathrm{Ag} / \mathrm{Ag}_{2} \mathrm{MoO}_{4}$ during the photocatalytic process, in which both holes and $\bullet \mathrm{OH}$ radicals were found to play crucial role in photocatalytic removal of $\mathrm{RhB}$ under visible light irradiation. A possible photocatalytic mechanism of $\mathrm{Ag} / \mathrm{Ag}_{2} \mathrm{MoO}_{4}$ was finally proposed on the basis of all the results to explain the higher photocatalytic activity of the octahedral $\mathrm{Ag} / \mathrm{Ag}_{2} \mathrm{MoO}_{4}$ composites. It was inferred that the photoinduced "hot" electrons can quickly transfer from the Ag NPs to the conduction band of $\mathrm{Ag}_{2} \mathrm{MoO}_{4}$ and react with oxygen and $\mathrm{H}_{2} \mathrm{O}$ to generate a large quality of active radicals such as $\bullet \mathrm{OH}$ and $\bullet \mathrm{O}_{2}{ }^{-}$because of the SPR effects. Besides, this SPR effects of Ag nanoparticles deposited on the surface of $\mathrm{Ag}_{2} \mathrm{MoO}_{4}$ can not only dramatically amplify its light absorption, especially in the visible region, but also promote the separation of photoexcited electron-hole pairs and effectively decrease electron-hole recombination.
\end{abstract}

(C) 2016, Dalian Institute of Chemical Physics, Chinese Academy of Sciences. Published by Elsevier B.V. All rights reserved.

\section{Introduction}

In the past decades, semiconductor photocatalysis has at- tracted worldwide interest because of its potential applications in the fields of environment and energy [1-6]. $\mathrm{TiO}_{2}$, as the most popular photocatalyst has been extensively studied because of

\footnotetext{
* Corresponding author. Tel/Fax: +86-27-87288246; E-mail: hchenhao@mail.hzau.edu.cn

\# Corresponding author. Tel/Fax: +86-27-87288246; E-mail: dingx@mail.hzau.edu.cn

This work was supported by Fundamental Research Funds for the Central Universities (2662014BQ061, 2015PY120, 2015PY047, 2016PY088), and the National Natural Science Foundation of China (51572101, 21502059, 21607047).

DOI: 10.1016/S1872-2067(16)62553-6 | http://www.sciencedirect.com/science/journal/18722067 | Chin. J. Catal., Vol. 38, No. 2, February 2017
} 
its abundance, stability and nontoxicity $[7,8]$. However, $\mathrm{TiO}_{2}$ is only responsive to ultraviolet (UV) light $(\lambda<400 \mathrm{~nm})$, which is only about $4 \%$ of the spectrum of sunlight, leading to low photoconversion efficiency [9]. Therefore, many researchers have attempted to improve the photocatalytic efficiency of $\mathrm{TiO}_{2}$ under visible light through modifications such as doping with transition metals and nonmetal atoms, as well as developing other visible light-responsive semiconductor photocatalysts [10-12]. Various visible-light photocatalysts including doped classical photocatalysts, dye-sensitized photocatalysts, heterojunction photocatalysts and other composite semiconductor photocatalysts have been explored through different channels [13-17].

Among the original visible-light photocatalysts, those with deposited noble metals have received much attention recently, because the localized surface plasmon resonance (SPR) effect of the noble metals can both dramatically amplify the visible-light absorption of the semiconductor and markedly improve the rate of electron-hole separation at the metal/semiconductor interface [18-20]. For instance, Huang et al. $[21,22]$ reported a series of silver (Ag)-silver halide ( $\mathrm{AgX})$ plasmonic photocatalysts synthesized through photoreduction of AgX that showed improved photocatalytic activity in the degradation of methyl orange (MO) compared with that of $\mathrm{AgX}$ alone. Ye et al. [23] also found that necklace-like $\mathrm{Ag} / \mathrm{Ag}_{3} \mathrm{PO}_{4}$ heterostructures fabricated through a hetero-growth process, where uniform, ordered $\mathrm{Ag}_{3} \mathrm{PO}_{4}$ submicrocubes formed on the Ag nanowires, displayed high MO degradation efficiency. Recently, Shen and colleagues [24] demonstrated that $\mathrm{Ag}_{2} \mathrm{Mo}_{2} \mathrm{O}_{7} @ \mathrm{AgBr}-\mathrm{Ag}$ composites allowed effective photocatalytic removal of both methylene blue and rhodamine $\mathrm{B}(\mathrm{RhB})$.

Molybdates, which play important roles in various technological applications, are promising photocatalysts because of their unique structural, physical, and chemical properties $[25,26]$. As a vital member of the molybdate family, silver molybdate $\left(\mathrm{Ag}_{2} \mathrm{MoO}_{4}\right)$ has been widely used in photoluminescence and surface-enhanced Raman scattering (because of its suitable physical and chemical properties $[27,28]$. To date, multifarious nano- and microstructures of $\mathrm{Ag}_{2} \mathrm{MoO}_{4}$ have been fabricated, including nanoparticles (NPs), wire-like nanostructures, and even flower-like microstructures [29,30]. However, the photocatalytic activity of $\mathrm{Ag}_{2} \mathrm{MoO}_{4}$ has rarely been observed, except for that of a cube-like $\mathrm{Ag} / \mathrm{Ag}_{2} \mathrm{MoO}_{4}$ composite recently prepared via a harsh microwave-assisted hydrothermal process in the presence of polyvinylpyrrolidone [31]. The function of different active species and the corresponding photocatalytic mechanism of $\mathrm{Ag} / \mathrm{Ag}_{2} \mathrm{MoO}_{4}$ composites have never been deeply investigated. Therefore, it is of great significance to develop a new route to fabricate $\mathrm{Ag} / \mathrm{Ag}_{2} \mathrm{MoO}_{4}$ composites under milder reaction conditions and examine their photocatalytic mechanism.

In this study, novel octahedral $\mathrm{Ag} / \mathrm{Ag}_{2} \mathrm{MoO}_{4}$ composites with SPR-enhanced photocatalytic performance are fabricated by a facile one-pot hydrothermal route in the presence of sodium dodecyl sulfate (SDS). The crystal structure, morphology and optical properties of the as-prepared samples are systematically investigated by a series of characterization methods in- cluding X-ray diffraction (XRD), scanning electron microscopy (SEM), and UV-visible diffuse reflectance absorption spectroscopy (DRS). The photocatalytic activities of the as-prepared composites are subsequently evaluated by the degradation of RhB under visible-light irradiation. Various control experiments are performed to gain a deep understanding of the assembly of $\mathrm{Ag} / \mathrm{Ag}_{2} \mathrm{MoO}_{4}$ composites. The roles of reaction conditions such as $\mathrm{pH}$, reaction time, and the amount of surfactant added in the formation of octahedral microstructure are studied in detail. In addition, the photocatalytic mechanism of the $\mathrm{Ag} / \mathrm{Ag}_{2} \mathrm{MoO}_{4}$ composites is also systematically investigated. This study provides a new strategy to achieve enhanced photocatalytic performance for other types of photocatalysts besides $\mathrm{TiO}_{2}$.

\section{Experimental}

\subsection{Preparation}

All reagents were analytical grade, and used as raw materials without any further purification. Deionized water was used throughout the syntheses. The $\mathrm{Ag} / \mathrm{Ag}_{2} \mathrm{MoO}_{4}$ composites were synthesized via a hydrothermal process. In a typical synthesis, $\left(\mathrm{NH}_{4}\right)_{6} \mathrm{Mo}_{7} \mathrm{O}_{24} \cdot 4 \mathrm{H}_{2} \mathrm{O}(0.286 \mathrm{mmol})$ and SDS $(0,0.2,0.5$, or $0.6 \mathrm{~g})$ were first dissolved in deionized water $(20 \mathrm{~mL})$. Then $\mathrm{AgNO}_{3}$ solution $\left(0.133 \mathrm{~mol} \mathrm{~L}^{-1}, 15 \mathrm{~mL}\right)$ was added dropwise to the above solution under constant vigorous magnetic stirring for $30 \mathrm{~min}$. The $\mathrm{pH}$ of the mixture was adjusted to the desired value $(2,3,4,5,6,7$, or 8$)$ by addition of $\mathrm{NH}_{3} \cdot \mathrm{H}_{2} \mathrm{O}$ or $\mathrm{HNO}_{3}$ solution. The resulting mixture was then transferred into a $50-\mathrm{mL}$ stainless steel autoclave with a Teflon liner. After treating the mixture at $180{ }^{\circ} \mathrm{C}$ for a time of $2,4,8,14$, or $24 \mathrm{~h}$, the resulting product was cooled to room temperature. The precipitate was collected by centrifugation, washed with deionized water and absolute ethanol several times, and then dried at $60{ }^{\circ} \mathrm{C}$ overnight.

\subsection{Characterization}

The purity and crystallinity of the as-prepared composites were characterized by XRD using a diffractometer (Bruker D8 Advanced, USA) with $\mathrm{Cu} K_{\alpha}$ over the $2 \theta$ range from $5^{\circ}$ to $80^{\circ}$. The morphologies and microstructures of the samples were observed by SEM (JSM-6390LV, Japan). DRS data for the samples were acquired using a Cary 5000 UV-vis-NIR spectrophotometer equipped with an integrating sphere using $\mathrm{BaSO}_{4}$ as the reflectance standard.

\subsection{Photocatalytic activity evaluation}

$\mathrm{RhB}$ was chosen as the target organic compound in this study to estimate the photocatalytic activity of the photocatalysts. During a typical test of RhB degradation, photocatalyst (20 mg) was dispersed in RhB solution (50 mL) with an initial concentration of $20 \mathrm{mmol} \mathrm{L}^{-1}$ in a photoreactor via vigorous stirring. Before exposure to light, the suspension was stirred in the dark for $30 \mathrm{~min}$ to establish an adsorption-desorption equi- 
librium. After adsorption, the photocatalytic reaction was irradiated with a 300-W Xe lamp (PLS-SXE300C) serving as the simulated solar light source. A light filter $(\lambda>420 \mathrm{~nm})$ was used to remove UV light from the light source. During the photocatalytic process, aliquots of the reaction solution were removed from the photoreactor at regular intervals, centrifuged, and then filtered to remove the catalyst particles before analysis. RhB concentration was monitored using a UV-vis spectrophotometer (Shimadzu, UV-3600).

\subsection{Photoelectrochemical experiments}

Photocurrent measurements were carried out in a standard three-electrode cell containing $\mathrm{Na}_{2} \mathrm{SO}_{4}$ aqueous solution (0.5 mol L-1) on a CHI 660E workstation (Shanghai). Platinum foil and a saturated calomel electrode were used as the counter and reference electrodes, respectively. The working electrode was prepared as described in elsewhere [32,33]. A 300-W Xe lamp with a $420-n m$ cutoff filter was used as the visible light source. All electrochemical measurements were performed at room temperature.

In addition, to investigate the photocatalytic mechanism of the composites, the active species during the photocatalytic degradation were detected through a series of trapping experiments. These experiments were conducted with $1 \mathrm{mmol} \mathrm{L}^{-1}$ $\mathrm{K}_{2} \mathrm{Cr}_{2} \mathrm{O}_{7}$ (quenches photoinduced electrons), triethanolamine (TEOA; quenches holes), isopropanol (IPA; quenches hydroxyl radicals $[\bullet \mathrm{OH}])$, or p-benzoquinone (BQ; quenches superoxide radicals $\left[\bullet_{2}^{-}\right]$) in the reaction solution.

\section{Results and discussion}

\subsection{Crystal structure of $\mathrm{Ag} / \mathrm{Ag}_{2} \mathrm{MoO}_{4}$}

The purity and crystallinity of the as-prepared composites were first studied by XRD to determine the effects of $\mathrm{pH}$, reaction time and amount of SDS in the hydrothermal process on the crystal structure of the $\mathrm{Ag} / \mathrm{Ag}_{2} \mathrm{MoO}_{4}$ photocatalyst. XRD patterns of composites prepared at different $\mathrm{pH}$ values are shown in Fig. 1(a). All the diffraction peaks of the sample prepared under neutral conditions $(\mathrm{pH}=7)$ could be indexed to the cubic phase of $\mathrm{Ag}_{2} \mathrm{MoO}_{4}$ (JCPDS 08-0473). The strong intensity of the diffraction peaks indicated the high purity and crystallinity of $\mathrm{Ag}_{2} \mathrm{MoO}_{4}$ prepared at $\mathrm{pH}=7$. No obvious diffraction peaks of $\mathrm{Ag}^{0}$ were observed in the pattern, which is attributed to the small content and weak diffraction intensity of Ag NPs deposited on the surface of $\mathrm{Ag}_{2} \mathrm{MoO}_{4}$. Different from the $\mathrm{Ag} / \mathrm{Ag}_{2} \mathrm{MoO}_{4}$ composite obtained at $\mathrm{pH}=7$, the diffraction peaks of the sample prepared at $\mathrm{pH}=3$ were assigned to the triclinic phase of $\mathrm{Ag}_{2} \mathrm{Mo}_{2} \mathrm{O}_{7}$ (JCPDS 75-1505, $a=6.095 \AA, b=$ $7.501 \AA, c=9.3127 \AA, \alpha=110.4^{\circ}, \beta=93.3^{\circ}$, and $\gamma=113.5^{\circ}$ ). As for the sample obtained at $\mathrm{pH}=5$, its diffraction peaks could be ascribed to a mixture of the cubic phase of $\mathrm{Ag}_{2} \mathrm{MoO}_{4}$ and triclinic phase of $\mathrm{Ag}_{2} \mathrm{Mo}_{2} \mathrm{O}_{7}$, implying that the crystalline phase of the samples gradually transformed from the cubic phase of $\mathrm{Ag}_{2} \mathrm{MoO}_{4}$ to the triclinic phase of $\mathrm{Ag}_{2} \mathrm{Mo}_{2} \mathrm{O}_{7}$ as the $\mathrm{pH}$ was adjusted from neutral to acidic. When the $\mathrm{pH}$ of the reaction was
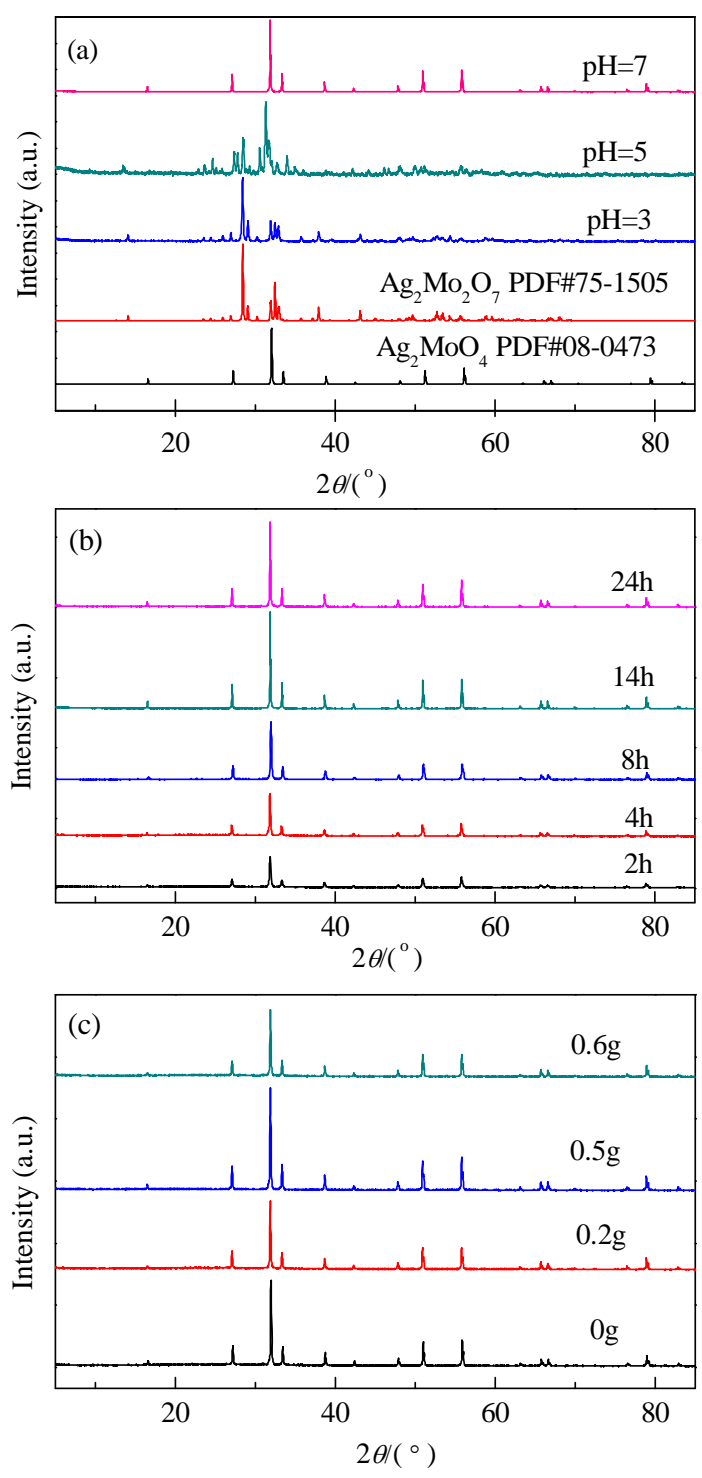

Fig. 1. XRD patterns of the composites obtained using different $\mathrm{pH}$ values (a), reaction times (b), and SDS dosages (c).

fixed at 7, no obvious change of the crystal structure of $\mathrm{Ag} / \mathrm{Ag}_{2} \mathrm{MoO}_{4}$ was observed when other conditions were varied (Fig. 1(b) and (c)), and all the diffraction peaks could be well indexed to the standard pattern of cubic phase of $\mathrm{Ag}_{2} \mathrm{MoO}_{4}$. These results reveal that $\mathrm{pH}$ strongly influenced the crystal structure of the composites. Fan et al. [34] recently reported similar results.

\subsection{Morphology of $\mathrm{Ag} / \mathrm{Ag}_{2} \mathrm{MoO}_{4}$}

The morphologies of composites synthesized by a hydrothermal process under different conditions were characterized by SEM to gain a deep insight into the effect of various reaction conditions on the assembly of $\mathrm{Ag} / \mathrm{Ag}_{2} \mathrm{MoO}_{4}$ composites. SEM images of the composites obtained at different $\mathrm{pH}$ values are shown in Fig. 2. The product prepared at $\mathrm{pH}=7$ (other conditions: $160{ }^{\circ} \mathrm{C}, 14 \mathrm{~h}$, and $0.5 \mathrm{~g}$ of SDS) had an octahedral morphology with a size of 6-8 $\mu \mathrm{m}$ (Fig. 2(a)). It is worth noting that 


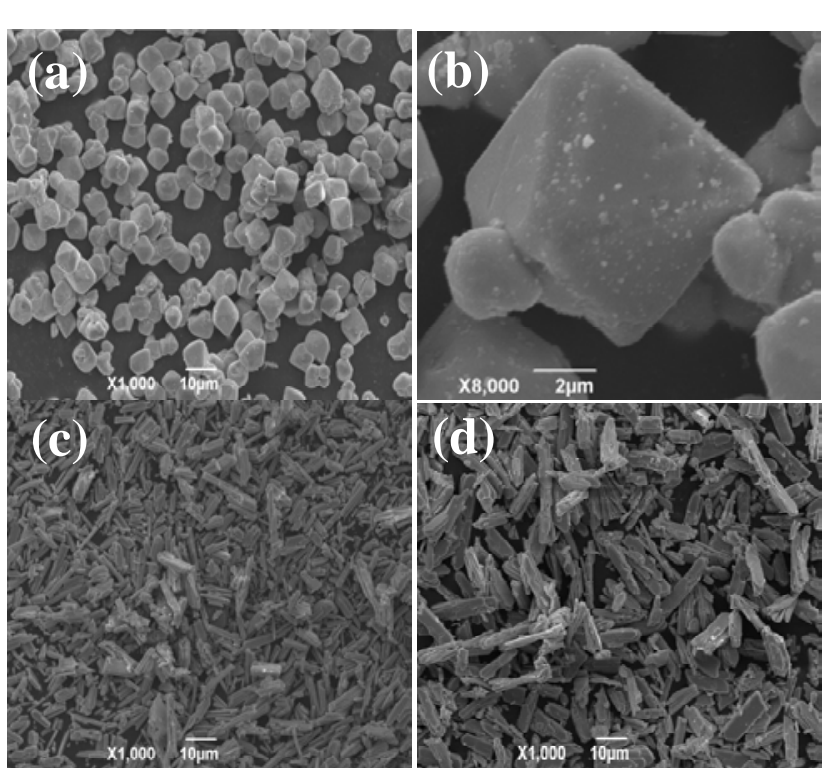

Fig. 2. SEM images at different magnifications of the composites obtained at $\mathrm{pH}$ of 7 (a, b), 3 (c), and 5 (d).

some brighter dots were observed on the surface of the octahedral microcrystals (Fig. 2(b)), which are considered to be Ag NPs according to previous reports $[35,36]$. The Ag NPs dispersed on the surface of the $\mathrm{Ag}_{2} \mathrm{MoO}_{4}$ microcrystals had a particle size range of $10-50 \mathrm{~nm}$. Distinct from the octahedral $\mathrm{Ag} / \mathrm{Ag}_{2} \mathrm{MoO}_{4}$ composites, only some irregular flaky aggregates were observed when the reaction $\mathrm{pH}$ was changed to 3 or 5 (Fig. 2(c) and (d), respectively).

The whole growth process of the octahedral microcrystals was elucidated through morphology observation of samples prepared with different reaction times, as illustrated in Fig. 3. After 2 or $4 \mathrm{~h}$ treatment at $160{ }^{\circ} \mathrm{C}$ with $0.5 \mathrm{~g}$ of SDS, only some irregular particles were obtained. After extending the reaction time to 8 or $14 \mathrm{~h}$, most of the products were octahedral $\mathrm{Ag} / \mathrm{Ag}_{2} \mathrm{MoO}_{4}$ composites, and their morphology became more regular with lengthening reaction time. However, a very long reaction time was found to be unfavorable for the formation of the octahedral composites. The sample morphology became
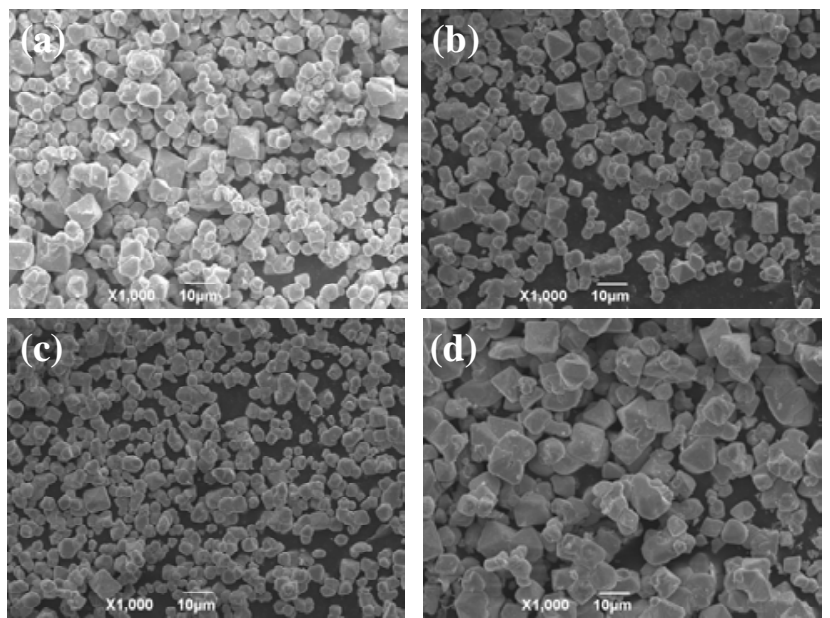

Fig. 3. SEM images of the composites obtained using different reaction times. (a) 2 h; (b) 4 h; (c) 8 h; (d) 24 h. more irregular with some polyhedral particles in the final products obtained when the reaction time was extended to 24 h. These observations above clearly indicate that the reaction time of the current synthetic procedure is important for the morphology control of the resulting $\mathrm{Ag} / \mathrm{Ag}_{2} \mathrm{MoO}_{4}$ composites, and an appropriate reaction time is $14 \mathrm{~h}$.

As a typical surfactant, SDS is known to influence the morphologies of products synthesized by hydrothermal processes $[37,38]$. A similar phenomenon was also found in this study. As indicated in Fig. 4, in the absence of SDS, only irregular particles were obtained. When 0.2 or $0.5 \mathrm{~g}$ of SDS was added into the reaction system, octahedral $\mathrm{Ag} / \mathrm{Ag}_{2} \mathrm{MoO}_{4}$ composites gradually formed, and their morphology changed regularly as the amount of SDS was increased. When excess SDS $(0.6 \mathrm{~g}$ ) was added, the resulting composites were irregular with some oversized particles. These results suggest that the surfactant SDS affects the synthesis of octahedral $\mathrm{Ag}-\mathrm{Ag}_{2} \mathrm{MoO}_{4}$ composites, and the optimal amount of SDS is $0.5 \mathrm{~g}$. It was speculated that the specific adsorption and structural induction properties of SDS might promote the synthesis of the octahedral $\mathrm{Ag} / \mathrm{Ag}_{2} \mathrm{MoO}_{4}$ composites under suitable conditions. As a widely used surfactant or emulsifier, each SDS molecule possesses a long dodecyl chain and sulfate anion. The lone electron pairs of the sulfate anion can coordinate with the $\mathrm{Ag}$ atoms on the surface of $\mathrm{Ag}_{2} \mathrm{MoO}_{4}$ nanocrystals, forming a strong coordination bond, while the long dodecyl chain surrounds the faces of the $\mathrm{Ag}_{2} \mathrm{MoO}_{4}$ nanocrystals. These factors make SDS an effective surfactant to modify crystal growth and lead to the faceted octahedral structure. It is noteworthy that all the samples obtained under neutral conditions were dark red. A high-magnification SEM image of one of these samples (not shown) revealed dispersed $\mathrm{Ag}$ NPs on their surface, which indicates the formation of $\mathrm{Ag}$ NPs was related to $\mathrm{pH}$ rather than the amount of SDS.

\subsection{XPS analysis}
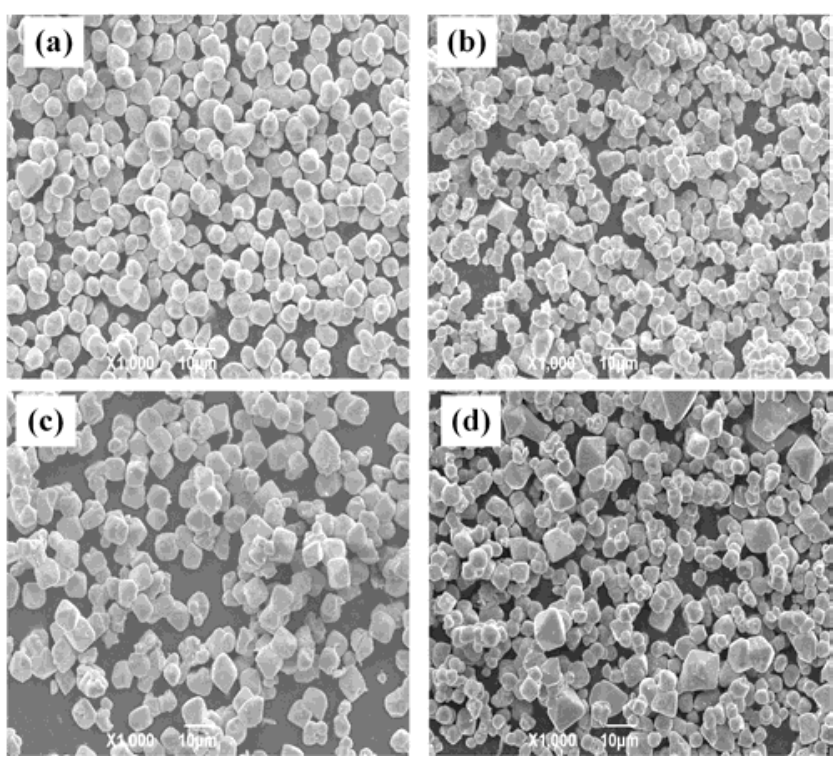

Fig. 4. SEM images of the composites obtained with different amounts of SDS. (a) $0 \mathrm{~g}$; (b) $0.2 \mathrm{~g}$; (c) $0.5 \mathrm{~g}$; (d) $0.6 \mathrm{~g}$. 
The chemical compositions and states of surface elements in the as-prepared $\mathrm{Ag} / \mathrm{Ag}_{2} \mathrm{MoO}_{4}$ composites were investigated by XPS analysis. Fig. 5(a) depicts a typical XPS survey scan of an $\mathrm{Ag} / \mathrm{Ag}_{2} \mathrm{MoO}_{4}$ composite, which is composed of the four elements $\mathrm{Ag}, \mathrm{O}, \mathrm{Mo}$, and a trace amount of $\mathrm{C}$, which is ascribed to contaminant carbon species originating from the air and precursors. The high-resolution XPS scan of Ag in Fig. 5(b) contains peaks at binding energies of 367.60 and $373.60 \mathrm{eV}$, which can be ascribed to Ag $3 d_{5 / 2}$ and $\mathrm{Ag} 3 d_{3 / 2}$, respectively, and divided into four different peaks. The peaks at 367.62 and 373.64 $\mathrm{eV}$ were derived from $\mathrm{Ag}^{+}$, while the other two peaks were assigned to $\operatorname{Ag}^{0}$ [39], confirming the generation of Ag NPs, consistent with the SEM analysis. Fig. 5(c) displays a high-resolution spectrum of Mo3d, in which the peaks at binding energies of 234.9 and $232.4 \mathrm{eV}$ correspond to Mo $3 d_{3 / 2}$ and Mo $3 d_{5 / 2}$, respectively. A new peak at $229.7 \mathrm{eV}$ attributed to $\mathrm{Mo}^{4+}$ was observed, meaning $\mathrm{Mo}^{6+}$ was partially reduced to $\mathrm{Mo}^{4+}$ to realize charge compensation during the formation of Ag NPs. Chen et al. [40] recently reported similar findings. Fig. 5(d) shows the $01 s$ region for the $\mathrm{Ag} / \mathrm{Ag}_{2} \mathrm{MoO}_{4}$ composite. It can be divided into two peaks at 528.13 and $530.13 \mathrm{eV}$, which are assigned to $\mathrm{O}-\mathrm{Ag}$ and $\mathrm{O}-\mathrm{Mo}$ bonds, respectively.

\subsection{Optical properties and photocatalytic performance of $\mathrm{Ag} / \mathrm{Ag}_{2} \mathrm{MoO}_{4}$}

The optical properties of the products were characterized by DRS. Fig. 6 shows the absorption spectra of the composites obtained under different reaction conditions. A blue shift was observed as the crystalline phase of the samples gradually transformed from the triclinic phase of $\mathrm{Ag}_{2} \mathrm{Mo}_{2} \mathrm{O}_{7}$ to the cubic
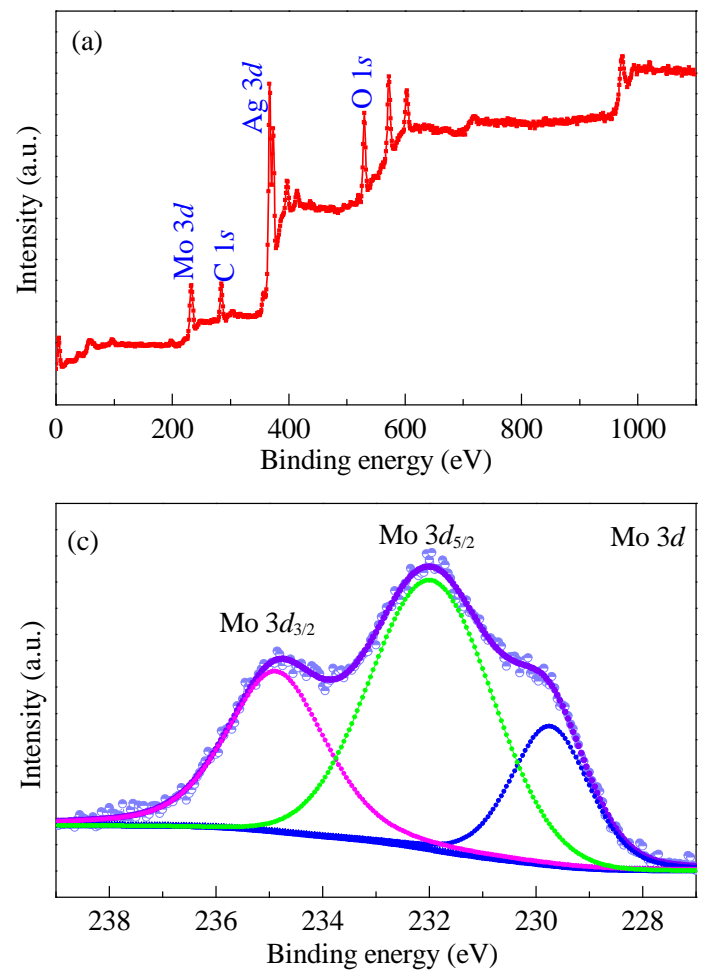

phase of $\mathrm{Ag}_{2} \mathrm{MoO}_{4}$ with changing pH (Fig. 6(a)). The pure $\mathrm{Ag}_{2} \mathrm{Mo}_{2} \mathrm{O}_{7}$ sample prepared under acidic conditions only absorbed UV light with a wavelength shorter than $420 \mathrm{~nm}$. When the $\mathrm{pH}$ was adjusted to neutral, the light absorption of the composite was dramatically amplified, especially in the visible region. This enhancement in light absorption can be ascribed to the localized SPR and interband UV excitation of Ag NPs deposited on the surface of $\mathrm{Ag}_{2} \mathrm{MoO}_{4}$. The optical band gap of the samples was calculated using the optical absorption data near the band edge. The estimated band gap for $\mathrm{Ag}_{2} \mathrm{MoO}_{4}$ was 3.24 eV (inset in Fig. 6(a)), which means $\mathrm{Ag}_{2} \mathrm{MoO}_{4}$ may not respond to visible light.

The effects of reaction time and amount of SDS in the hydrothermal process on the optical properties of the resulting $\mathrm{Ag} / \mathrm{Ag}_{2} \mathrm{MoO}_{4}$ photocatalysts are illustrated in Fig. 6(b) and (c), respectively. No obvious change of the band gap (3.15 eV) of the samples was observed when the hydrothermal time was increased from 2 to $24 \mathrm{~h}$, while the absorption of visible light rose and then declined (Fig. 6(b)). The product obtained after $14 \mathrm{~h}$ of hydrothermal treatment possessed the strongest visible-light absorption of the composites. These results indicate that the size of Ag NPs dispersed on the surface of $\mathrm{Ag}_{2} \mathrm{MoO}_{4}$ would be excessively large when the reaction time was prolonged to $24 \mathrm{~h}$, which is unfavorable for SPR, leading to the observed decrease of visible-light absorption. The effects of SDS dosage on the optical properties of the resulting composites appeared to be similar to that of hydrothermal reaction time. As shown in Fig. 6(c), the visible-light absorption of the as-prepared samples first enhanced gradually with increasing SDS dosage and then decreased markedly when the SDS dosage exceeded $0.5 \mathrm{~g}$, implying that the optimal amount of SDS was
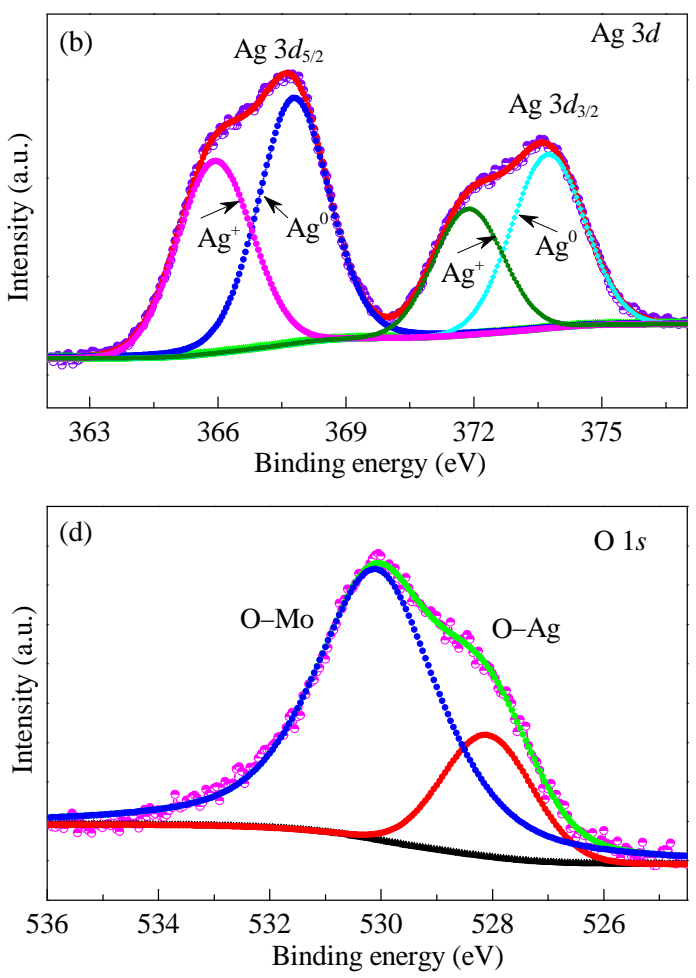

Fig. 5. XPS survey scan and high-resolution (a), Mo $3 d$ (b), Bi $4 f(c)$ and $01 s$ (d) spectra of $\mathrm{Ag} / \mathrm{Ag}_{2} \mathrm{MoO}_{4}$. 

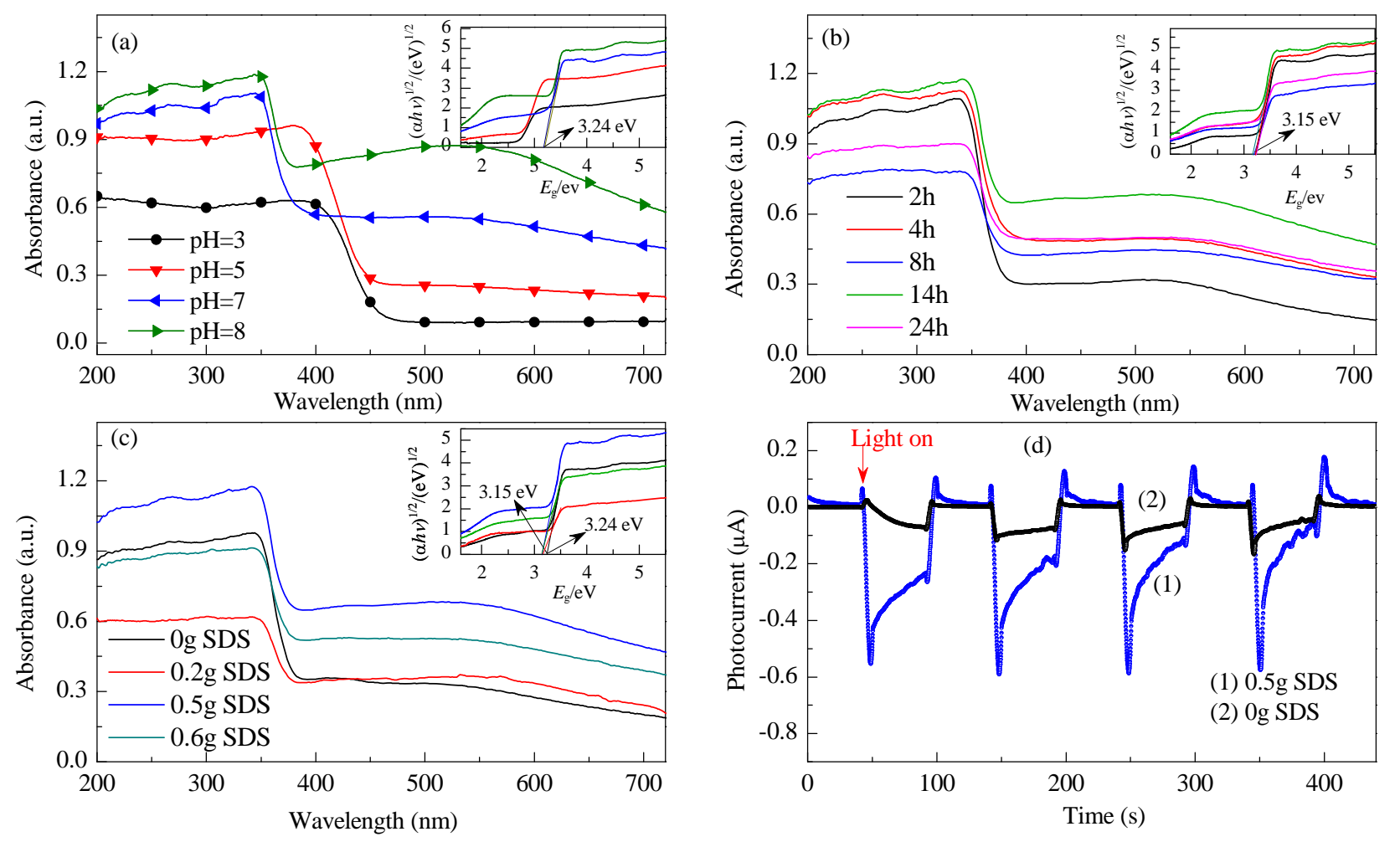

Fig. 6. UV-vis diffuse reflectance spectra of composites prepared using different pH (a), reaction times (b), and SDS dosages (c). (d) Photocurrent response of $\mathrm{Ag} / \mathrm{Ag}_{2} \mathrm{MoO}_{4}$ prepared using different SDS dosages.

0.5 g. Moreover, the band gap of the samples gradually narrowed from 3.24 to $3.15 \mathrm{eV}$ as the amount of SDS was increased from 0 to $0.5 \mathrm{~g}$. All of these results indicate that the appropriate reaction time and amount of SDS in this study are $14 \mathrm{~h}$ and 0.5 $\mathrm{g}$, respectively. The enhanced visible-light absorption caused by SPR means the photogenerated carrier concentration of $\mathrm{Ag} / \mathrm{Ag}_{2} \mathrm{MoO}_{4}$ increased correspondingly. This was subsequently confirmed by photocurrent measurements. Fig. 6(d) reveals that the photocurrent generation of $\mathrm{Ag} / \mathrm{Ag}_{2} \mathrm{MoO}_{4}$ prepared with an SDS dosage of $0.5 \mathrm{~g}$ is much higher than that of the composite produced without using SDS.

The photocatalytic activities of the as-prepared composites were evaluated by their ability to degrade RhB solutions under visible-light irradiation; the results are presented in Figs. 7 and 8. The blank photolysis experiment without photocatalyst in Fig. 7(a) did not show any observable decrease in RhB concentration over time, demonstrating that photocatalysis was indeed the cause of the decomposition of RhB. Almost 70\% of the $\mathrm{RhB}$ molecules were decomposed within $150 \mathrm{~min}$ in the aqueous solution containing octahedral $\mathrm{Ag} / \mathrm{Ag}_{2} \mathrm{MoO}_{4}$ composite,

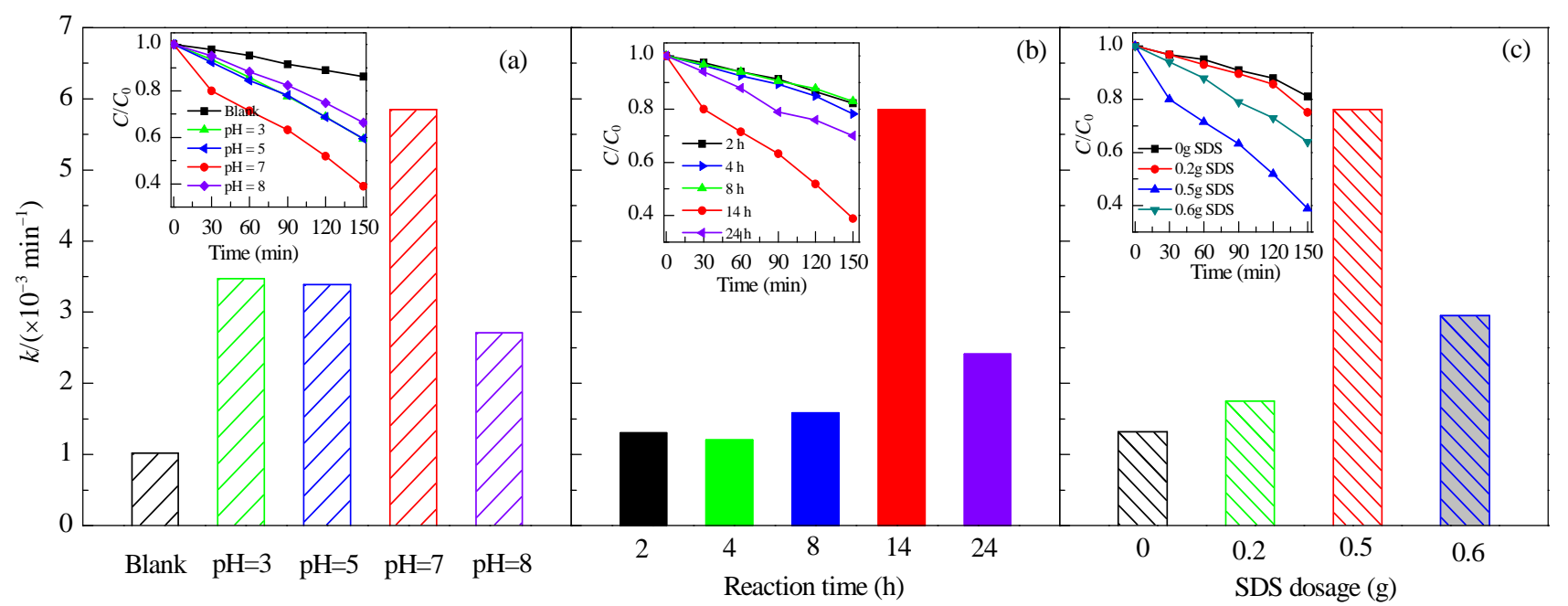

Fig. 7. Photocatalytic degradation of RhB by composites prepared using different pH (a), reaction times (b), and SDS dosages (c). 
while the other photocatalysts only degraded $40 \%-50 \%$ of the $\mathrm{RhB}$ in the solution in the same time. Fig. 7(b) and (c) display the photocatalytic activity variation of the $\mathrm{Ag} / \mathrm{Ag}_{2} \mathrm{MoO}_{4}$ composites with the change of reaction time and SDS dosage, respectively, which increased and then decreased at neutral $\mathrm{pH}$. The $\mathrm{Ag} / \mathrm{Ag}_{2} \mathrm{MoO}_{4}$ composite prepared at $160{ }^{\circ} \mathrm{C}$ for $14 \mathrm{~h}$ with $0.5 \mathrm{~g}$ of SDS possessed the highest activity of the composites of $5.89 \times 10^{-3} \mathrm{~min}^{-1}$. Combined with the results of SEM, XPS and DRS analyses, it can be inferred that the highest photocatalytic activities of this composite was caused by the presence of the proper amount of deposited Ag NPs with SPR.

\subsection{Photocatalytic mechanism of $\mathrm{Ag} / \mathrm{Ag}_{2} \mathrm{MoO}_{4}$}

Capture experiments were carried out to clarify the function of different active species generated on the surface of $\mathrm{Ag} / \mathrm{Ag}_{2} \mathrm{MoO}_{4}$ during the photocatalytic process. TEOA, $\mathrm{K}_{2} \mathrm{Cr}_{2} \mathrm{O}_{7}$, IPA, and BQ were used as hole, electron, $\bullet \mathrm{OH}$, and $\bullet \mathrm{O}_{2}{ }^{-}$scavengers, respectively, during the photocatalytic degradation of RhB (Figs. 9 and 8(d)). In Fig. 9(a), the slight RhB removal efficiency decrease induced by the presence of $\mathrm{BQ}$ suggested that $\bullet \mathrm{O}_{2}{ }^{-}$did not contribute much to the photocatalytic degradation of RhB over $\mathrm{Ag} / \mathrm{Ag}_{2} \mathrm{MoO}_{4}$. In contrast, the addition of TEOA had a dramatic negative effect on RhB degradation, implying that holes played an indispensable role in photocatalytic removal of RhB. Meanwhile, about $58.1 \%$ of RhB degradation was inhibited when $\bullet \mathrm{OH}$ was captured by IPA (Fig. 9b), thereby indicating
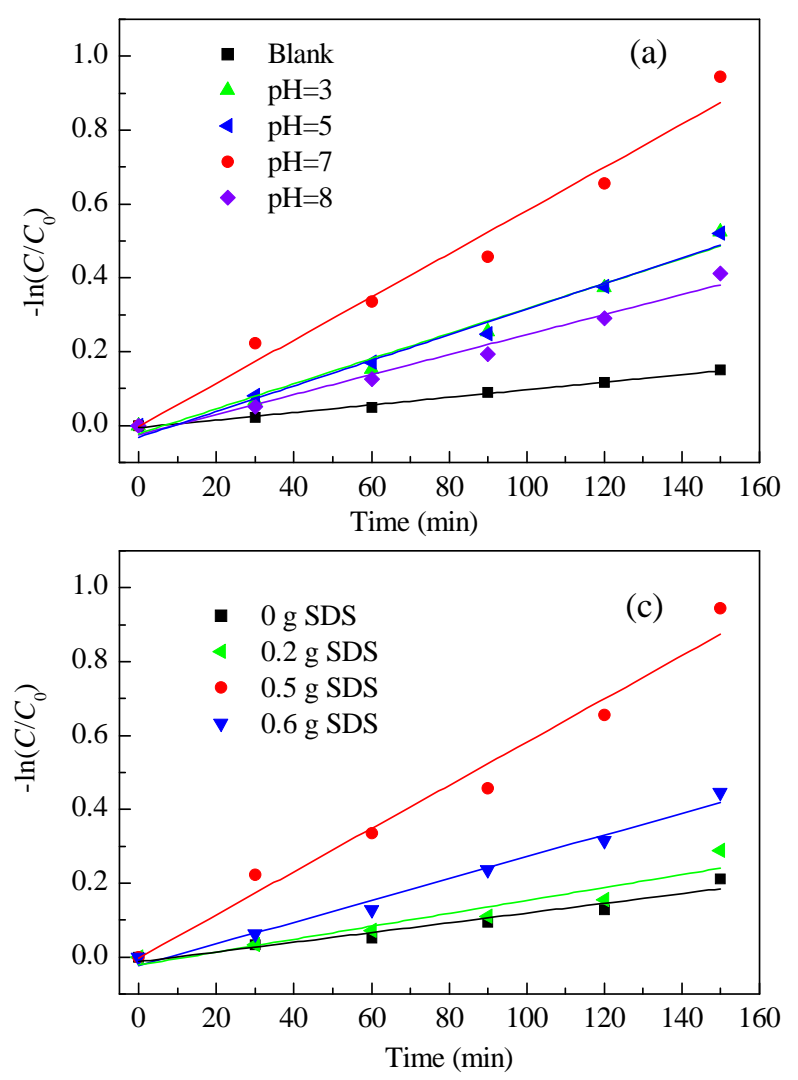

that $\bullet \mathrm{OH}$ also played an important role in $\mathrm{RhB}$ photocatalytic degradation. It is noteworthy that the RhB photocatalytic degradation was dramatically enhanced by the addition of $\mathrm{K}_{2} \mathrm{Cr}_{2} \mathrm{O}_{7}$. This might be attributed to the electron trapping role of $\mathrm{K}_{2} \mathrm{Cr}_{2} \mathrm{O}_{7}$ inhibiting the recombination of electron-hole pairs, and thus leaving more holes to oxidize $\mathrm{RhB}$, further confirming the crucial function of holes in the photocatalytic removal of $\mathrm{RhB}$ by the $\mathrm{Ag} / \mathrm{Ag}_{2} \mathrm{MoO}_{4}$ composites.

Based on the above results, a possible photocatalytic mechanism of $\mathrm{Ag} / \mathrm{Ag}_{2} \mathrm{MoO}_{4}$ was proposed to explain the higher photocatalytic activity of the octahedral $\mathrm{Ag} / \mathrm{Ag}_{2} \mathrm{MoO}_{4}$ composite than those of all the other prepared products. As shown in Fig. 10, upon light irradiation, electromagnetic waves will be greatly confined and amplified in certain interfacial areas when the oscillation frequency of electrons belonging to Ag NPs matches that of the light. Consequently, the SPR of Ag NPs deposited on the surface of $\mathrm{Ag}_{2} \mathrm{MoO}_{4}$ can not only dramatically amplify light absorption, especially in the visible region, but also promote the effective separation of photoexcited electron-hole pairs and decrease the probability of electron-hole recombination. As a result, photoinduced electron-hole pairs are generated in the Ag NPs through SPR. The photoinduced "hot" electrons would quickly transfer from the Ag NPs to the conduction band of $\mathrm{Ag}_{2} \mathrm{MoO}_{4}$ because of the SPR effects. The photoexcited electrons and holes then effectively react with oxygen and $\mathrm{H}_{2} \mathrm{O}$ to generate a large quality of active radicals such as $\bullet \mathrm{OH}$ and $\bullet \mathrm{O}_{2}{ }^{-}$, thereby leading to the high photocatalytic activities of the
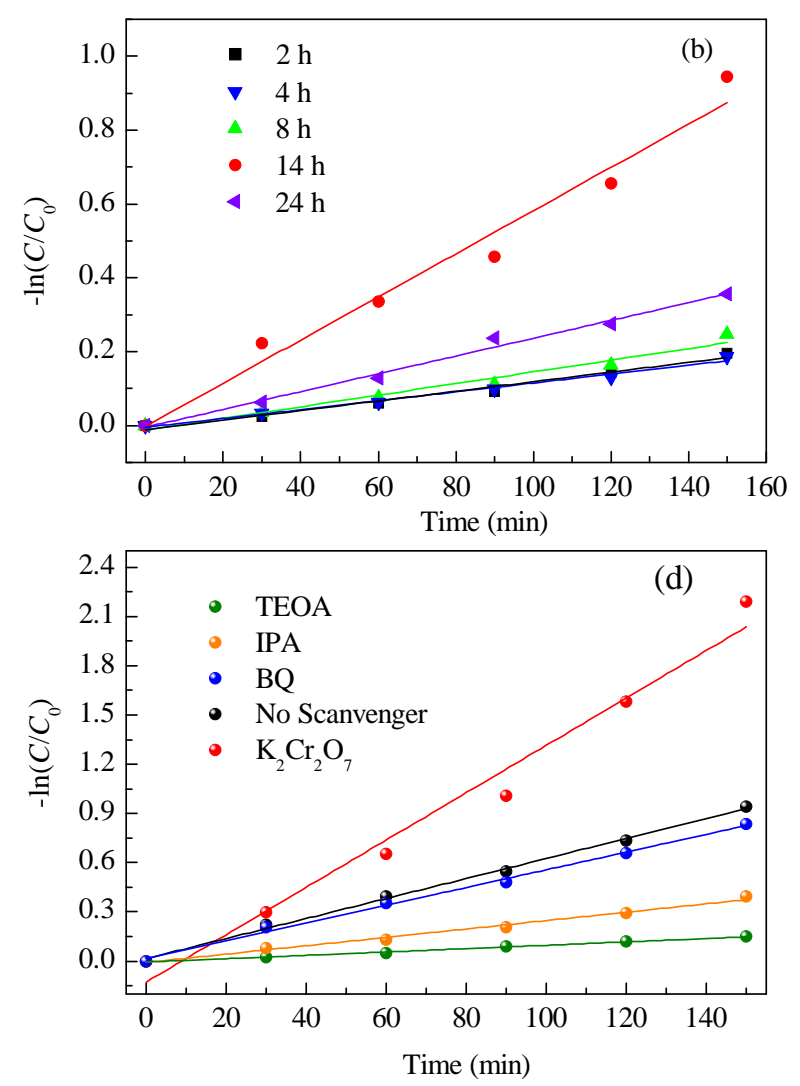

Fig. 8. Dependence of $\ln \left(C / C_{0}\right)$ on reaction time during photocatalytic degradation of SA over samples prepared using different pH (a), reaction times (b), and SDS dosages(c), and over $\mathrm{Ag} / \mathrm{Ag}_{2} \mathrm{MoO}_{4}$ with addition of different scavengers (d). 

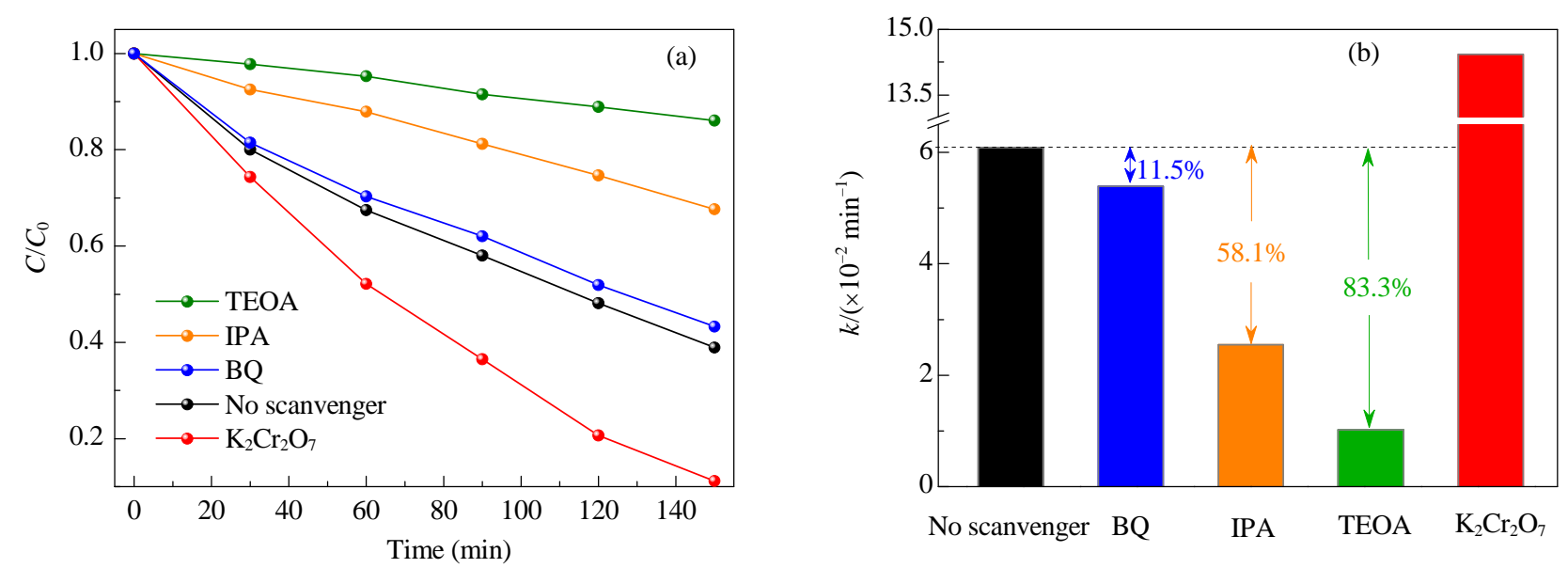

Fig. 9. Photocatalytic degradation of $\mathrm{RhB}$ (a) and corresponding pseudo first-order kinetic constants (b) over $\mathrm{Ag} / \mathrm{Ag}_{2} \mathrm{MoO}_{4}$ composites under visible-light irradiation with different scavengers ( $\mathrm{BQ} \rightarrow \bullet \mathrm{O}_{2}^{-} ; \mathrm{TEOA} \rightarrow$ holes; $\mathrm{K}_{2} \mathrm{Cr}_{2} \mathrm{O}_{7} \rightarrow \mathrm{e}^{-} ; \mathrm{IPA} \rightarrow \bullet \mathrm{OH}$ ).

as-prepared $\mathrm{Ag} / \mathrm{Ag}_{2} \mathrm{MoO}_{4}$ composites in $\mathrm{RhB}$ decomposition.

\section{Conclusions}

In this work, we developed novel $\mathrm{Ag} / \mathrm{Ag}_{2} \mathrm{MoO}_{4}$ composites displaying SPR-enhanced photocatalytic performance through a facile one-pot hydrothermal route with the addition of SDS. A variety of controlled experiments were carefully conducted to gain a deep insight into the assembly of $\mathrm{Ag} / \mathrm{Ag}_{2} \mathrm{MoO}_{4}$ composites. Reaction conditions, such as $\mathrm{pH}$, reaction time, and the amount of surfactant, played crucial roles in the formation of the octahedral microstructure of the composites. The photocatalytic activity of the $\mathrm{Ag} / \mathrm{Ag}_{2} \mathrm{MoO}_{4}$ composites towards $\mathrm{RhB}$ under visible-light irradiation was investigated. The results demonstrated that the product obtained at $160^{\circ} \mathrm{C}$ using $0.5 \mathrm{~g}$ of SDS exhibited the most efficient photocatalytic degradation of $\mathrm{RhB}$ of the composites under visible-light irradiation, which could be attributed to the SPR effect.

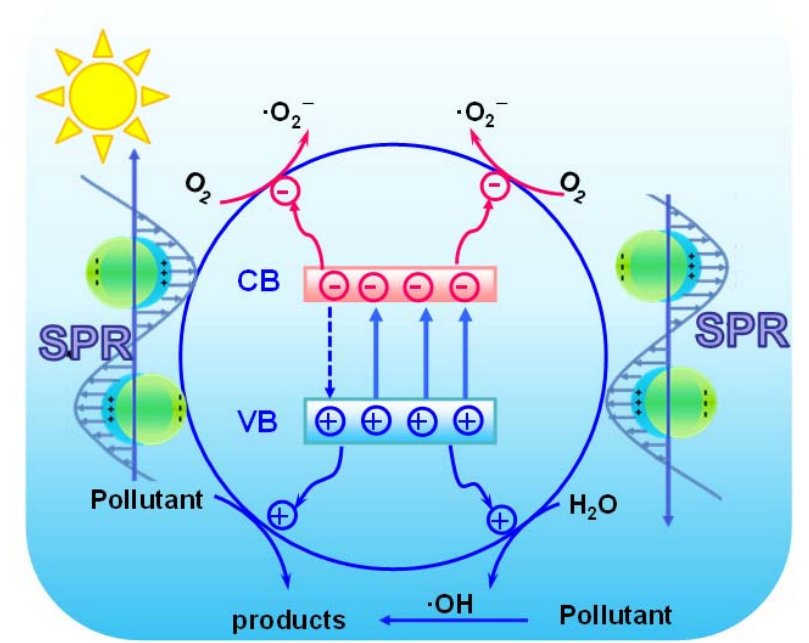

Fig. 10. Photocatalytic mechanism of the $\mathrm{Ag} / \mathrm{Ag}_{2} \mathrm{MoO}_{4}$ composites under visible-light irradiation.

\section{References}

[1] A. Fujishima, K. Honda., Nature, 1972, 238, 37-38.

[2] X. B. Chen, S. S. Mao, Chem. Rev., 2007, 107, 2891-2959.

[3] A. Kudo, Y. Miseki, Chem. Soc. Rev., 2009, 38, 253-278.

[4] D. Li, W. D. Shi, Chin. J. Catal., 2016, 37 792-799.

[5] Y. F. Zhao, X. D. Jia, G. I. N. Waterhouse, L. Z. Wu, C. H. Tung, D. O'Hare, T. R. Zhang, Adv. Energy Mater., 2016, 1501974, 1-20.

[6] D. T. Yue, X. F. Qian, Y. X. Zhao, Sci. Bull., 2015, 60, 1791-1806.

[7] R. Asahi, T. Morikawa, T. Ohwaki, K. Aoki, Y. Taga, Science, 2001, 293, 269-271.

[8] H. G. Yang, C. H. Sun, S. Z. Qiao, J. Zou, G. Liu, S. C. Smith, H. M. Cheng, G. Q. Lu, Nature, 2008, 453, 638-641.

[9] H. Tong, S. X. Ouyang, Y. P. Bi, N. Umezawa, M. Oshikiri, J. H. Ye, Adv. Mater., 2012, 24, 229-251.

[10] S. Sakthivel, M. V. Shankar, M. Palanichamy, B. Arabindoo, D. W. Bahnemann, V. Murugesan, Water Res., 2004, 38, 3001-3008.

[11] X. C. Wang, K. Maeda, A. Thomas, K. Takanabe, G. Xin, J. M. Carlsson, K. Domen, M. Antonietti, Nat. Mater., 2009, 8, 76-80.

[12] J. L. Wang, C. Wang, W. B. Lin, ACS Catal, 2012, 2, 2630-2640.

[13] X. H. Zhang, L. J. Yu, C. S. Zhuang, T. Y. Peng, R. J. Li, X. G. Li, ACS Catal., 2013, 4, 162-170.

[14] C. Chen, W. M. Cai, M. Long, B. X. Zhou, Y. H. Wu, D. Y. Wu, Y. J. Feng, ACS Nano, 2010, 4, 6425-6532.

[15] K. Awazu, M. Fujmaki, C. Rockstuhl, J. Tominaga, H. Murakami, Y. Ohki, N. Yoshida, T. Watanabe, J. Am. Chem. Soc., 2008, 130, 1676-1680.

[16] J. G. Yu, S. H. Wang, J. X. Low, W. Xiao, Phys. Chem. Chem. Phys., 2013, 15, 16883-16890.

[17] C. Zhou, Y. F. Zhao, L. Shang, R. Shi, L. Z. Wu, C. H. Tung, T. R. Zhang, Chem. Commun., 2016, 52, 8239-8242.

[18] H. Zhang, X. F. Fan, X. Quan, S. Chen, H. T. Yu, Environ. Sci. Technol,, 2011, 45, 5731-5736.

[19] J. J. Chen, J. C. S. Wu, P. C. Wu, D. P. Tsai, J. Phy. Chem. C, 2011, 115, 210-216.

[20] G. G. Liu, P. Li, G. X. Zhao, X. Wang, J. T. Kong, H. M. Liu, H. B. Zhang, K. Chang, X. G. Meng, T. Kako, J. H. Ye, J. Am. Chem. Soc., 2016, 138, 9128-9136. 


\section{Graphical Abstract}

Chin. J. Catal., 2017, 38: 260-269 doi: 10.1016/S1872-2067(16)62553-6

Surface plasmon resonance-induced visible-light photocatalytic performance of silver/silver molybdate composites

Xianglong Yang, Ying Wang, Xiao Xu, Yang Qu, Xing Ding *, Hao Chen*

Huazhong Agricultural University

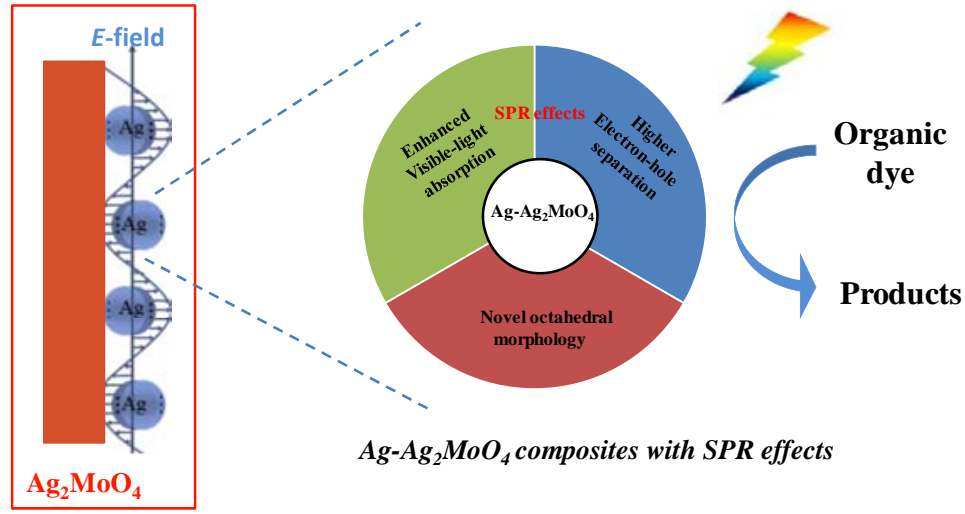

Novel octahedral silver/silver molybdate composites prepared by a one-pot hydrothermal route exhibited favorable photocatalytic performance under visible-light irradiation. The photocatalytic mechanism based on surface plasmon resonance of the silver nanoparticles was determined via capture experiments.

[21] P. Wang, B. B. Huang, X. Y. Qin, X. Y. Zhang, Y. Dai, J. Y. Wei, M. H. Whangbo, Angew. Chem. Int. Ed., 2008, 47, 7931-7933.

[22] P. Wang, B. B. Huang, Q. Q. Zhang, X. Y. Zhang, X. Y. Qin, Y. Dai, J. Zhan, J. X. Yu, H. X. Liu, Z. Z. Lou, Chem. Eur. J., 2010, 16, 10042-10047.

[23] Y. P. Bi, H. Y. Hu, S. X. Ouyang, Z. B. Jiao, G. X. Lu, J. H. Ye, J. Mater. Chem., 2012, 22, 14847-14850.

[24] C. C. Shen, Q. Zhu, Z. W. Zhao, T. Wen, X. K. Wang, A. W. Xu, J. Mater. Chem. A, 2015, 3, 14661-14668.

[25] M. Shen, X. H. Zhang, K. Dai, H. Chen, T. Y. Peng, CrystEngComm, 2013, 15, 1146-1152.

[26] J. L. Long, S. C. Wang, H. J. Chang, B. Z. Zhao, B. T. Liu, Y. G. Zhou, W. Wei, X. X. Wang, L. Huang, W. Huang, Small, 2014, 10, 2791-2795.

[27] A. F. Gouveia, J. C. Sczancoski, M. M. Ferrer, A. S. Lima, M. R. M. C. Santos, M. S. Li, R. S. Santos, E. Longo, L. S. Cavalcante, Inorg. Chem., 2014, 53, 5589-5599.

[28] E. K. Fodjo, D. W. Li, N. P. Marius, T. Albert, Y. T. Long, J. Mater. Chem. A, 2013, 1, 2558-2566.

[29] D. P. Singh, B. Sirota, S. Talpatra, P. Kohli, C. Rebholz, S. M. Aouadi, J. Nanoparticle. Res., 2012, 14, 781-791.
[30] F. S. Cunha, J. C. Sczancoski, I. C. Nogueira, V. G. de Oliveira, S. M. C. Lustosa, E. Longo, L. S. Cavalcante, CrystEngComm, 2015, 17, 8207-8211.

[31] Z. Q. Li, X. T. Chen, Z. L. Xue, Sci. China Chem., 2013, 56, 443-450.

[32] J. Jiang, Z. Kun, X. J. Xiao, L. Z. Zhang, J. Am. Chem. Soc., 2012, 134, 4473-4476.

[33] J. L. Wang, Y. Yu, L. Z. Zhang, Appl. Catal. B, 2013, 136, 112-121.

[34] C. F. Fan, T. Bian, L. Shang, R. Shi, L. Z. Wu, C. H. Tung, T. R. Zhang, Nanascale, 2016, 8, 3923-3925.

[35] Y. P. Liu, L. Fang, H. D. Lu, Y. W. Li, C. Z. Hu, H. G. Yu, Appl. Catal. B, 2012,115, 245-252.

[36] Y. P. Liu, L. Fang, H. D. Lu, L. J. Liu, H. Wang, C. Z. Hu, Catal. Comm., 2012, 17, 200-204.

[37] L. Kvítek, A. Panáček, J. Soukupová, M. Kolář, R. Večeřová, R. Prucek, M. Holecová, R. Zbořil, J. Phys. Chem. C, 2008, 112, 5825-5834.

[38] J. Y. Ho, M. H. Huang, J. Phys. Chem. C, 2009, 113, 14159-14164.

[39] Y. Y. Bai, Y. Lu, J. K. Liu, J. Hazard. Mater., 2016, 307, 26-35.

[40] Z. Dai, F. Qin, H. P. Zhao, J. Ding, Y. L. Liu, R. Chen, ACS Catal., 2016, 6, 3180-3192.

\section{具有SPR 效应的 $\mathrm{Ag} / \mathrm{Ag}_{2} \mathrm{MoO}_{4}$ 材料在可见光区的光催化性能研究

\author{
杨祥龙, 王 尹, 徐骁, 篗阳, 丁 星 ${ }^{\#}$, 陈 浩 ${ }^{*}$ \\ 华中农业大学理学院, 湖北武汉 430070
}

摘要: 作为一类新兴的光催化材料, 钼酸盐纳米材料具有高表面能、多活性位点和高选择性等优点, 在可见光催化降解污 染物方面有着重要应用, 近年来受到广泛关注. 作为钼酸盐家族重要的一员, 钼酸银在杀菌、表面增强拉曼光谱、气敏材 料等方面均有重要应用, 但其光催化性能却鲜见报道. 这是由于它的光谱响应范围窄和广生载流子分离效率低所致. 虽然 近来有少量基于钼酸银的复合材料的光催化研究, 但催化效果不佳. 众所周知, 作为自由电子体系, 诸多金属纳米粒子, 如 贵金属、碱金属等, 存在表面等离子体共振效应(SPR), 使得贵金属, 特别是 $\mathrm{Ag}, \mathrm{Au}$ 等纳米粒子在可见区域有较强的吸收. 利 
用这一特性, $\mathrm{Awazu}$ 等将 $\mathrm{Ag}$ 纳米颗粒沉积在 $\mathrm{TiO}_{2}$ 表面, 创造性地将SPR应用于光催化反应, 开发出在可见光谱区具有宽光 谱吸收特征的 $\mathrm{Ag} / \mathrm{TiO}_{2}$. 随后陆续合成出基于 $\mathrm{SPR}$ 效应的 $\mathrm{Ag} @ \mathrm{AgCl}, \mathrm{Ag} / \mathrm{Ag}_{3} \mathrm{PO}_{4}$ 材料均具有良好的光催化性能.

基于此, 本文在十二烷基硫酸钠(SDS)的存在下, 采用水热法一步合成了具有 $\mathrm{SPR}$ 效应的 $\mathrm{Ag} / \mathrm{Ag}_{2} \mathrm{MoO}_{4}$ 可见光催化材料, 并利用X射线粉末衍射(XRD)、紫外可见漫反射(DRS)、X射线光电子能谱(XPS)和扫描电子显微镜(SEM)等技术对材料进 行了表征. 系统地探讨了体系 $\mathrm{pH}$ 值、反应时间、表面活性剂用量对产物的晶相和微观形貌等的影响. 此外, 还利用罗丹明 B 降解实验考察了上述合成条件对材料可见光催化活性的影响, 并通过捕获剂实验深入地研究了起催化作用的活性物种.

$\mathrm{XRD}$ 结果表明, 体系的 $\mathrm{pH}$ 值对材料的晶型有极大影响, 随着 $\mathrm{pH}$ 由酸性变至中性、碱性, 最终得到的钼酸银也由 $\mathrm{Ag}_{2} \mathrm{Mo}_{2} \mathrm{O}_{7}$ 过渡到 $\mathrm{Ag}_{2} \mathrm{MoO}_{4}$. SEM图显示在最优条件 ( $\mathrm{pH}$ 为7, 加入 $0.5 \mathrm{~g} \mathrm{SDS}, 160{ }^{\circ} \mathrm{C}$ 下水热 $14 \mathrm{~h}$ )下制得的钼酸银为八面体的 $\mathrm{Ag}_{2} \mathrm{MoO}_{4}$, 且其表面均匀地分布着 $\mathrm{Ag}$ 纳米颗粒, 与XPS图谱结果一致. 另外表面活性剂SDS的用量对所合成材料的形貌影 响很大. 本文可一步得到以八面体 $\mathrm{Ag}_{2} \mathrm{MoO}_{4}$ 为主的 $\mathrm{Ag} / \mathrm{Ag}_{2} \mathrm{MoO}_{4}$ 复合材料, 是因为 $S D S$ 的疏水长链可以诱导 $\mathrm{Ag}_{2} \mathrm{MoO}_{4}$ 的各 向异性生长. DRS 结果表明, $\mathrm{Ag}_{2} \mathrm{MoO}_{4}$ 八面体上 $\mathrm{Ag}$ 颗粒的引入使其在可见光区的吸收明显加强, 因而它在可见光下催化降 解罗丹明B降解反应活性增加. 捕获剂实验结果表明, 起决定性作用的活性物种是光生空穴, 另外・OH也起了一定作用.

关键词: 银; 钿酸银; 十二烷基硫酸钠; 光催化活性; 表面等离子体共振效应; 罗丹明B

收稿日期: 2016-08-23. 接受日期: 2016-09-10. 出版日期: 2017-02-05.

*通讯联系人. 电话/传真: (027)87288246; 电子信箱: hchenhao@mail.hzau.edu.cn

\#通讯联系人. 电话/传真: (027)87288246; 电子信箱: dingx@mail.hzau.edu.cn

基金来源：中央高校基本科研专项资金(2662014BQ061，2015PY120，2015PY047，2016PY088); 国家自然科学基金(51572101, 21502059, 21607047).

本文的英文电子版由Elsevier出版社在ScienceDirect上出版(http://www.sciencedirect.com/science/journal/18722067). 